\title{
Uma nova versão para um velho versinho
}

Eu sou um cara mole

Que só anda duro

Passei a noite em claro

No meu quarto escuro

Passei o tempo inteiro

Desse meio tempo

Preso à liberdade

Do meu pensamento

Falei por alto

Mas bem baixinho

Você é um bom pedaço

De mau caminho

Eu tenho andado certo

De que há algo errado

Nossas vidas se separam tanto

Enquanto a gente tem se misturado

Você me fez um carão

Eu te fiz um carinho

E sussurrei uma nova versão

Para um velho versinho

E quando vi o teu sorriso

Senti então realizado

Aquele sonho adormecido

De só sonhar acordado

\footnotetext{
${ }^{1}$ Aluno do curso de Licenciatura em Letras Língua Portuguesa/Língua Francesa, da Universidade Federal de Campina Grande (UFCG). E-mail: evertonformare@bol.com.
} 